\title{
PENGEMBANGAN PERANGKAT PEMBELAJARAN GEOMETRI SMP MENGGUNAKAN METODE PENEMUAN TERBIMBING PADA KELAS VIII SEMESTER II
}

\author{
Yuliyanto ${ }^{1)}$, Jailani ${ }^{2)}$ \\ SMP Negeri 1 Muntilan Jawa Tengah ${ }^{1)}$, Universitas Negeri Yogyakarta ${ }^{2)}$ \\ mr_yulitenan@yahoo.co.id ${ }^{1)}$, zailani_uny@yahoo.com ${ }^{2)}$
}

\begin{abstract}
Abstrak
Penelitian ini bertujuan untuk menghasilkan perangkat pembelajaran geometri SMP yang berkualitas baik/layak digunakan dalam proses pembelajaran dan mendeskripsikan kualitas hasil pengembangan perangkat pembelajaran tersebut. Kualitas hasil pengembangan ditentukan berdasarkan pada kriteria dari Nieveen, yaitu valid, praktis dan efektif. Penelitian ini merupakan penelitian pengembangan. Model pengembangan perangkat pembelajaran dalam penelitian ini diadaptasi dari model pengembangan Dick \& Carey. Tahap-tahap yang dilakukan meliputi (1) analisis kebutuhan dan perumusan tujuan; (2) pengembangan produk; (3) validasi, uji coba, dan revisi; serta (4) kajian produk akhir. Uji coba dilaksanakan dalam tiga tahap, yaitu (1) uji coba/validasi ahli; (2) uji coba skala kecil; dan (3) uji coba skala besar/lapangan. Penelitian ini menghasilkan perangkat pembelajaran geometri SMP yang berkualitas dan layak digunakan dalam proses pembelajaran. Masing-masing komponen perangkat pembelajaran tersebut memenuhi kriteria sangat valid, sangat praktis dan efektif.
\end{abstract}

Kata kunci: pengembangan, perangkat pembelajaran, geometri SMP, penemuan terbimbing

\section{DEVELOPING GEOMETRICS INSTRUCTIONAL PACKAGE FOR JUNIOR HIGH SCHOOL USING GUIDED DISCOVERY METHOD IN GRADE VIII, SEMESTER II}

\begin{abstract}
This research is aimed to produce a qualified geometrics instructional package which is suitable for SMP students and describe the quality of the developed product. This quality is determined based on Niveen criteria, including validity, practicality and effectiveness. This research is a developmental research. The model of the instructional package in this research was adapted from Dick and Carey development model. The steps cover (1) analysis of the need and establishment of the goals; (2) development of the product, (3) validation, try out, and revision; and (4) final product review. The try out was done in three stages, i.e. (1) try out/ expert judgment; (2) small group try out; and (3) field try out. The research produced geometrics instructional package for SMP which is qualified and suitable in the teaching learning process. Each instructional package component is valid, practical, and effective.
\end{abstract}

Keywords: development, instructional package, Junior High School Geometrics, guided discovery 


\section{PENDAHULUAN}

Berdasarkan Standar Isi untuk Satuan Pendidikan Dasar dan Menengah, secara ringkas tujuan pembelajaran matematika pada jenjang SMP adalah agar peserta didik memiliki kemampuan: (1) memahami konsep; (2) menggunakan penalaran; (3) memecahkan masalah; (4) mengomunikasikan gagasan; dan (5) memiliki sikap menghargai matematika (BSNP, 2006, p.140). Ketercapaian tujuan tersebut sangat bergantung pada proses pembelajaran di kelas yang dilaksanakan guru sebagai agen pembelajaran dengan kompetensi yang mendukungnya, yaitu kompetensi pedagogik dan profesional. Hal ini sejalan dengan yang tertuang dalam Peraturan Pemerintah Republik Indonesia Nomor 19 Tahun 2005 tentang Standar Nasional Pendidikan pasal 28 ayat (1) bahwa "guru harus memiliki kemampuan untuk mewujudkan tujuan pendidikan nasional" (Depdiknas, 2005, p.21).

Sebagai bagian yang penting dalam keberhasilan pendidikan, kompetensi pedagogik dan profesional guru merupakan dua kompetensi yang perlu mendapat perhatian lebih dibanding kompetensi lainnya. Kondisi di Kabupaten Magelang saat ini menunjukkan bahwa masih banyak guru matematika yang kesulitan dalam merencanakan dan melaksanakan proses pembelajarannya di kelas. Hasil uji coba uji kompetensi dari 112 orang guru matematika di Kabupaten Magelang dalam rentang nilai 0-10 menunjukkan bahwa rata-rata nilai kompetensi pedagogik 5,65, sedangkan untuk kompetensi profesional nilai rata-ratanya 8,29 . Ini berarti secara materi guru sudah cukup menguasai, tetapi dalam pembelajaran seperti masih mengalami kesulitan dalam hal memfasilitasi peserta didik untuk membangun pengetahuannya melalui proses pembelajaran. Kondisi tersebut mempengaruhi guru dalam membuat perencanaan pembelajarannya. Salah satu akibat dari rendahnya kompetensi tersebut adalah guru tidak mengembangkan silabus dan RPP sebagai bagian dari kegiatan perencanaan pembelajarannya, melainkan mencarinya dengan berbagai cara di antaranya meng-copy dari teman, atau dengan cara mengadopsi contoh-contoh silabus dan RPP yang sudah ada, diantaranya dari MGMP dan internet. Hasil wawancara tertulis dengan 12 orang guru matematika di Kabupaten Magelang diperoleh data bahwa 58,33\% mengadaptasi silabus dan RPP yang dikembangkan di MGMP, $16,67 \%$ dengan cara download dari internet, dan $25 \%$ tidak memberikan jawaban atas pertanyaan tersebut. Hal ini bertentangan dengan yang tertuang dalam Permendiknas Nomor 41 Tahun 2007 tentang Standar Proses, bahwa "setiap guru pada satuan pendidikan berkewajiban menyusun RPP secara lengkap dan sistematis" (BSNP, 2007, p.2).

Selain itu, sebagian besar guru juga belum mengembangkan Lembar Kegiatan Siswa (LKS) dan instrumen penilaian yang merupakan pendukung silabus dan RPP sebagai bagian dari perangkat pembelajarannya. Hal ini diperkuat oleh hasil angket yang diberikan kepada 12 orang guru matematika di Kabupaten Magelang, yang menunjukkan bahwa, 4 orang $(33,33 \%)$ tidak mengembangkan LKS sendiri, 6 orang (50\%) kadang-kadang mengembangkan LKS sendiri, dan 2 orang $(16,67 \%)$ mengembangkan LKS sendiri. Untuk instrumen penilaian, 10 dari 12 orang guru $(83,33 \%)$ mengembangkan sendiri, dan 2 orang $(16,67 \%)$ kadang-kadang mengembangkan sendiri instrumen penilaiannya.

Hasil pengembangan silabus dan RPP oleh MGMP Matematika Kabupaten Magelang sendiri sampai saat ini masih belum sesuai dengan Permendiknas Nomor 41 Tahun 2007 Tentang Standar Proses. Salah satu bagian RPP hasil pengembangan di MGMP yang belum sesuai dengan peraturan tersebut adalah perumusan indikator pencapaian kompetensi dan tujuan pembelajaran. Tujuan pembelajaran yang dirumuskan hanya menggambarkan hasil, sedangkan proses yang menuju pencapaian hasil itu belum tampak. Hal lain yang belum sesuai dengan peraturan adalah uraian tentang materi ajar. (Disdikpora, 2011, pp.63-69).

Dalam RPP hasil pengembangan MGMP tersebut, antara indikator dan tujuan pembelajaran hanya dibedakan oleh kalimat "peserta didik dapat". Hal ini tidak sesuai dengan Permendiknas Nomor 41 Tahun 2007 Tentang Standar Proses yang menyatakan bahwa "tujuan pembelajaran menggambarkan proses dan hasil belajar yang diharapkan dicapai oleh peserta didik sesuai dengan kompetensi dasar" (BSNP, 2007, p.3). Materi ajar dalam RPP tersebut juga hanya dituliskan dengan materi pokok saja, sedangkan dalam Permendiknas Tentang Standar Proses menyatakan bahwa "materi ajar memuat fakta, konsep, prinsip, dan prosedur yang relevan, dan ditulis dalam bentuk butir-butir sesuai dengan rumusan indikator pencapaian kompetensi" (BSNP, 2007, p.3). Kenyataan tersebut menunjukkan bahwa perangkat pembelajaran yang dibuat oleh sebagian besar guru matematika di Kabupaten Magelang belum mengembangkan 
perangkat pembelajaran sesuai dengan prinsipprinsip penyusunan perangkat pembelajaran, sehingga diperlukan model/contoh pengembangan perangkat pembelajaran yang sesuai dengan prisip-prinsip penyusunan perangkat pembelajaran.

Materi pokok geometri yang dipilih dalam pengembangan ini merupakan salah satu topik di kelas VIII SMP semester II, yang kebanyakan siswa mengalami kesulitan dalam materi tersebut. Hal ini juga didukung oleh data daya serap hasil ujian nasional sebagai berikut: Berdasarkan data hasil ujian nasional di Kabupaten Magelang selama 4 (empat) tahun dari tahun 2008 sampai 2011, daya serap untuk materi pokok geometri selalu berada di bawah $60 \%$. Bahkan dalam kurun waktu 3 (tahun) terakhir pada rentang waktu tersebut, daya serap materi pokok geometri dalam ujian nasional cenderung mengalami penurunan. Hal ini menunjukkan bahwa di Kabupaten Magelang materi tersebut merupakan salah satu materi pokok yang dirasakan sulit oleh sebagian besar siswa.

Selanjutnya berdasarkan paradigma baru dalam pembelajaran yang berpusat pada siswa (student centered), proses pembelajaran harus memberikan ruang lebih banyak kepada siswa untuk membangun pengetahuan baru berdasarkan pengetahuan yang telah diperoleh sebelumnya. Hal ini didasarkan pada pandangan konstruktivis mengenai belajar yang menyatakan bahwa "learning has become knowledge construction" (Westwood, 2008, p.4). Oleh karena itu diharapkan guru merancang dan melaksanakan proses pembelajaran dengan menggunakan pendekatan kontekstual. Salah satu komponen dalam pendekatan kontekstual adalah kegiatan penemuan yang terbagi menjadi dua, yaitu penemuan murni dan penemuan terbimbing (guided discovery).

Mengenai keunggulan metode penemuan, Slameca \& Graf (Alfieri, 2011, p.3) menyatakan bahwa "discovery learning is efficacious because such learning involves the discovery and generation of general principles or explanation of domain-specific patterns after discovering such as one's own". Hal ini dapat diartikan bahwa pembelajaran dengan penemuan sangat mujarab karena proses pembelajaran memuat kegiatan penemuan dan penyusunan prinsipprinsip umum atau penjelasan pola dari umum kekhusus. Melalui proses pembelajaran menggunakan metode penemuan diharapkan siswa tidak hanya menghafal konsep matematika yang dipelajari, tetapi membangun sendiri konsep ter- sebut sehingga akan lebih mantap penguasaan konsep matematikanya.

Berbekal penguasaan konsep matematika yang mantap siswa diharapkan mampu menyelesaikan permasalahan matematika dengan tingkat berpikir yang lebih tinggi. Dengan demikian siswa tidak sekadar bisa menjawab pertanyaan berkaitan dengan "apa", tetapi juga bisa menjawab pertanyaan yang berkaitan dengan "bagaimana" bahkan "mengapa". Selanjutnya berdasarkan tingkat perkembangan intelektual siswa pada usia SMP, metode penemuan terbimbing lebih sesuai digunakan daripada penemuan murni.

Berdasarkan uraian tersebut maka perlu dilakukan sebuah penelitian tentang pengembangan perangkat pembelajaran geometri SMP dengan menggunakan metode penemuan terbimbing. Oleh karena itu metode pembelajaran yang digunakan dalam pengembangan perangkat pembelajaran ini adalah metode penemuan terbimbing.

Belajar merupakan sebuah proses membangun pengetahuan dan memaknai pengalaman yang telah diperoleh sebelumnya. Ini berarti, belajar bukanlah sebuah proses menyerap pengetahuan yang sudah menjadi bentukan guru, melainkan kegiatan aktif peserta didik dalam membangun pengetahuan yang dilakukan sendiri atau bersama orang lain. Hal ini sejalan dengan pendapat Westwood (2008, p.4) yang menyatakan bahwa "learning has become knowledge construction". Pembelajaran adalah proses yang melibatkan interaksi antara guru, siswa, dan lingkungan dalam rangka membantu siswa belajar untuk meraih sukses di sekolah melalui kegiatan membangun pengetahuan yang meliputi perencanaan, pelaksanaan, dan evaluasi. Hal ini sesuai dengan yang dikemukakan oleh Nitko \& Brookhart (2011, p.18) bahwa "instruction may be thought of as involving three fundamental but interrelated activities: (1) deciding what students are to learn; (2) carrying out the actual instruction; and (3) evaluating the learning". Pembelajaran harus difokuskan untuk membantu setiap siswa berprestasi dan sukses di sekolah, sesuai pendapat Ediger \& Rao (2010, p.18) yang menyatakan bahwa "teaching and learning must be focused upon helping each pupil to achieve well and succeed in school".

Pembelajaran matematika sekolah adalah proses pengemasan/penyajian materi matematika yang dilakukan oleh guru melalui perencanaan, pelaksanaan, dan penilaian secara berkesinambungan untuk memfasilitasi peserta didik 
dalam membangun pengetahuan baru berdasarkan pengetahuan yang sudah diperoleh sebelumnya menggunakan strategi tertentu dengan memperhatikan karakteristik matematika sekolah dan tingkat perkembangan mental siswa.

Pembelajaran matematika sekolah harus memperhatikan penyajiannya, artinya penyajian matematika sekolah tidak secara langsung berupa butir-butir matematika. Metode pembelajaran yang digunakan harus disesuaikan dengan tingkat perkembangan intelektual siswa. Hal ini mengisyaratkan kepada guru dalam proses pembelajarannya dapat menggunakan pola pikir induktif sebagai pola pikir matematika sekolah. Pembelajaran matematika sekolah juga dibatasi oleh semesta, dimulai dari yang sempit menuju yang lebih luas sesuai dengan tingkat perkembangan intelektual peserta didik. Selanjutnya objek matematika berupa fakta, konsep, operasi, dan prinsip harus disajikan dalam bentuk yang lebih kongkrit sesuai dengan tingkat penalaran peserta didik.

NCTM (2000, p.11) mengemukakan 6 (enam) prinsip dalam matematika sekolah, yaitu equity (keadilan), curriculum (kurikulum), teaching (pembelajaran), learning (belajar), assessment (penilaian), dan technology (teknologi). Prinsip pembelajaran secara langsung berkaitan dengan belajar, yaitu membantu siswa untuk mengembangkan pemahaman tentang konsep-konsep matematika, berpikir strategis tentang masalah, dan mengembangkan keterampilan proses. Prinsip belajar, maksudnya memahami bagaimana siswa belajar yang dituangkan dalam merancang kegiatan pembelajaran yang sesuai. Sedangkan prinsip penilaian menunjukkan interaksi berkelanjutan antara siswa dan guru sebelum, selama, dan setelah pembelajaran.

Pembelajaran matematika di sekolah harus memperhatikan standar isi dan standar proses yang telah ditetapkan. Standar ini berkaitan dengan cakupan materi yang harus dipelajari siswa. Sedangkan standar proses menunjuk pada proses matematis yang seharusnya siswa peroleh dan gunakan terkait dengan pengetahuan matematis. Hal ini sejalan dengan pendapat Van de Wale (2010, p.4) yang menyatakan bahwa "the process standards refer to the mathematical process through which students should acquire and use mathematical knowledge". Lebih lanjut Van de Wale (2010, pp.3-4) menyatakan enam standar proses pembelajaran matematika sekolah, yaitu problem solving (pemecahan masalah), reasoning and proof (memberikan alasan dan bukti), communication (komunikasi), connections (koneksi/hubungan), dan representation (penyajian).

Guru yang efektif sangat sistematis dalam persiapan, dan pelaksanaan dalam setiap pembelajarannya. Ini menunjukkan bahwa kegiatan pembelajaran akan efektif apabila direncanakan dan diatur dengan baik. Hal ini sesuai dengan pendapat Bob Moon (2002, p.54) menyatakan "the effective teacher is very systematic in the preparation for, and execution, of each lesson". O'Brien (2008, p.11) berpendapat bahwa "syllabus does include basic information, it can be an important learning tool help to you: convey to your students what matters to you about learning, ....". Ini berarti silabus merupakan salah satu perangkat yang penting dalam proses pembelajaran, karena dapat menjadi pedoman bagi guru dalam menyampaikan materi pembelajaran kepada siswa.

Disamping silabus, guru harus menyiapkan rencana pelaksanaan pembelajaran sebagai bagian utama dari kesuksesan dalam proses pembelajarannya. Hal ini sejalan dengan pendapat Altman (1992, p.4): “... the main purposes of a syllabus is to communicate to the students what the course is about, ... we have some idea about what we think the course should accomplish. It requires that we have planned the course". Pentingnya perencanaan dalam pembelajaran juga dikemukakan oleh Moursund (2012, p.5) dengan menyatakan "lesson plans and lesson planning are an important component of teaching". Ini menunjukkan bahwa rencana pembelajaran merupakan komponen penting yang harus ada dalam kegiatan pembelajaran. Pendapat ini sejalan dengan Singer (2003, p.70) yang menyatakan bahwa "lesson plans are necessary tools for teaching".

Berdasarkan uraian tersebut, yang dimaksud dengan perangkat pembelajaran dalam penelitian ini adalah silabus dan Rencana PelakSanaan Pembelajaran (RPP). Selanjutnya dalam Depdiknas (2008a, pp.8-9) tentang panduan pengembangan RPP dinyatakan bahwa langkahlangkah minimal yang harus dipenuhi pada setiap unsur kegiatan pembelajaran adalah: (1) kegiatan pendahuluan; (2) kegiatan inti; dan (3) kegiatan penutup. Dalam panduan tersebut secara khusus dinyatakan bahwa untuk memudahkan, biasanya kegiatan inti dilengkapi dengan Lembar Kegiatan Siswa (LKS), baik yang berjenis cetak atau non-cetak. Disamping itu dalam panduan tersebut juga dinyatakan bahwa sebuah rencana pelaksanaan pembelajaran (RPP) harus dilengkapi dengan perangkat penilaian yang 
dijabarkan atas teknik penilaian, bentuk instrumen, dan instrumen yang digunakan. Oleh karena itu komponen pendukung pengembangan perangkat pembelajaran dalam penelitian ini adalah berupa LKS dan instrumen tes hasil belajar.

Paradigma baru dalam pembelajaran menuntut perubahan proses dari pembelajaran yang berpusat pada guru (teacher centered) menjadi pembelajaran yang berpusat pada siswa (student centered). Pembelajaran yang berpusat pada siswa harus memberikan kesempatan lebih luas kepada siswa untuk membangun pengetahuan baru berdasarkan pengetahuan yang telah dimilikinya. Berdasarkan kurikulum berbasis kompetensi, terdapat 7 (tujuh) komponen utama dalam pembelajaran yang berpusat pada siswa, salah satunya adalah penyelidikan/penemuan (inquiry) (Depdiknas, 2002, p.5). Dalam penelitian ini akan digunakan istilah discovery untuk menyatakan penemuan, dan bukan inquiry. Ini dikarenakan di dalam matematika istilah pembelajaran dengan penemuan (discovery learning) lebih dikenal dengan baik daripada pembelajaran dengan penyelidikan (inquiry learning). Hal ini sejalan dengan pendapat yang mengatakan bahwa "discovery learning is perhaps the best-known form of inquiry-based learning" (Westwood, 2008, p.28).

Salah satu metode pembelajaran yang dapat diterapkan dalam pembelajaran matematika adalah metode penemuan. Hal ini sejalan dengan pendapat bahwa "metode pembelajaran discovery merupakan salah satu yang dapat digunakan untuk mencapai tujuan pembelajaran matematika" (Sri Lestari, 2008, p.312). Pendapat lain mengenai perlunya menggunakan metode penemuan dalam pembelajaran matematika dikemukakan oleh Julie (Suck, 2011, p.157): “in order for students to have an enriched mathematical experience it needs to be done through discovery. In order for students to have an enriched mathematical experience it needs to be done through discovery". Berdasarkan pendapat ini, pembelajaran matematika dengan penemuan memuat tujuan agar siswa memiliki pengalaman matematika yang lebih luas.

Metode penemuan terbimbing biasanya digunakan dengan bahan yang dikembangkan pebelajarnya secara induktif (Krismanto, 2003, p.4). Pembelajaran dengan penemuan terbimbing digunakan apabila di dalam kegiatan penemuan guru menyediakan bimbingan atau petunjuk yang cukup luas kepada siswa, dan seba- gian besar perencanaannya dibuat oleh guru. Mengenai metode penemuan terbimbing ini, Adkisson \& McCoy (Westwood, 2008, p.29) menyatakan bahwa "guided discovery is generally regarded as a motivating method, enjoyed by learners". Hal ini berarti bahwa metode penemuan terbimbing sangat dinikmati oleh siswa, karena metode ini lebih dianggap sebagai sebuah metode yang memotivasi siswa bagaimana mereka belajar.

Adapun langkah-langkah penggunaan metode penemuan terbimbing dalam penelitian ini adalah: (1) memberikan permasalahan kepada peserta didik dinyatakan menggunakan lembar kerja yang berisi pokok materi pelajaran yang akan dibahas beserta petunjuk langkah penyelesaian untuk mendapatkan suatu kesimpulan; (2) menyiapkan alat dan bahan untuk melakukan kegiatan penemuan; (3) diskusi pengarahan berupa pertanyaan-pertanyaan yang ditujukan kepada peserta didik untuk didiskusikan sebelum melakukan kegiatan penemuan; (4) kegiatan penemuan oleh peserta didik berupa kegiatan percobaan/penyelidikan secara kelompok untuk menemukan konsep-konsep atau prinsip-prinsip yang sedang dipelajari; (5) membantu peserta didik yang mengalami kesulitan dalam melakukan kegiatan penemuan; (6) presentasi hasil diskusi kelompok; (7) pengembangan masalah dan tindak lanjut.

Perangkat pembelajaran merupakan komponen yang sangat penting dalam proses pembelajaran di kelas. Perangkat pembelajaran dapat digunakan sebagai pedoman guru dalam melaksanakan proses pembelajaran di kelas sehingga proses pembelajaran bisa berlangsung lebih terarah menuju kompetensi yang akan dituju. Perancangan dan penggunaan perangkat pembelajaran yang baik diduga kuat dapat lebih meningkatkan hasil belajar siswa.

Berdasarkan uraian di atas, maka rumusan masalah dalam penelitian ini adalah: (1) Bagaimana mengembangkan perangkat pembelajaran matematika menggunakan metode penemuan terbimbing pada materi pokok geometri sesuai dengan prinsip dalam standar proses yang berlaku?; dan (2) Seberapa valid, praktis, dan efektif hasil pengembangan perangkat pembelajaran matematika menggunakan metode penemuan terbimbing pada materi pokok geometri?

\section{METODE PENELITIAN}

Jenis penelitian ini adalah penelitian pengembangan. Penelitian ini difokuskan pada pengembangan produk berupa silabus dan RPP 
serta kelengkapan komponen-komponenya. Produk yang dikembangkan yaitu silabus, rencana pelaksanaan pembelajaran (RPP), lembar kegiatan siswa (LKS), dan tes hasil belajar (THB). Model pengembangan yang digunakan dalam penelitian ini diadaptasi dari model pengembangan Dick \& Carey. Hal ini didasarkan pada langkah-langkah dalam model pengembangan tersebut lebih sesuai dengan kurikulum yang berlaku yaitu Kurikulum Tingkat Satuan Pendidikan (KTSP) yang berbasis kompetensi.

Berdasarkan langkah-langkah pengembangan model Dick \& Carey, tahapan dalam penelitian ini dibatasi sampai pada tahap evaluasi formatif. Tahap-tahap yang dilakukan meliputi (1) analisis kebutuhan dan perumusan tujuan; (2) pengembangan produk; (3) validasi, uji coba, dan revisi; serta (4) kajian produk akhir. Uji coba dilaksanakan dalam tiga tahap, yaitu (1) uji coba/validasi ahli; (2) uji coba skala kecil; dan (3) uji coba skala besar/la-pangan. Hasil validasi dan uji coba tersebut selanjutnya dijadikan sebagai bahan untuk melakukan perbaikan produk hingga diperoleh draft produk akhir.

\section{Prosedur Pengembangan}

Tahap analisis kebutuhan dan perumusan tujuan dilakukan dengan cara mengumpulkan informasi yang berkaitan dengan produk yang akan dikembangkan untuk mengatasi masalah yang ditemui dalam kegiatan pembelajaran geometri Sekolah Menengah Pertama (SMP). Pengumpulan informasi dilakukan dengan studi pustaka dan studi lapangan. Studi pustaka dilakukan dengan mempelajari konsep-konsep atau teori-teori yang berkenaan dengan pengembangan produk yang akan dihasilkan, karakteristik pembelajaran, dan karakteristik siswa. Studi lapangan dilakukan dengan melakukan observasi awal di lapangan untuk mengetahui pembelajaran yang berlangsung dan juga pengumpulan informasi berkaitan dengan silabus dan RPP yang digunakan guru. Analisis kebutuhan ini digunakan sebagai dasar untuk menentukan tujuan umum pembelajaran, yaitu kemampuan yang dibutuhkan siswa setelah melakukan proses pembelajaran.

Berdasarkan hasil analisis kebutuhan dan perumusan tujuan, selanjutnya ditetapkan indikator pencapaian kompetetensi, menentukan cakupan materi, merumusan alat untuk mengukur keberhasilan, dan beberapa hal lainnya yang terkait dengan persiapan pengembangan produk. Hasil ini selanjutnya digunakan sebagai dasar untuk melakukan pengembangan produk, yaitu perangkat pembelajaran geometri SMP pada materi bangun ruang sisi datar terdiri dari silabus, RPP, LKS, dan THB.

Tahap validasi ahli, uji coba, dan revisi dilakukan melalui validasi ahli (expert judgment), yaitu penilaian oleh beberapa ahli terhadap perangkat pembelajaran geometri SMP yang dihasilkan pada tahap II. Hal ini bertujuan untuk mengetahui apakah produk yang dihasilkan sudah sesuai dan layak digunakan atau tidak. Masukan-masukan dari ahli pada tahapan ini dijadikan sebagai dasar untuk melakukan revisi perangkat pembelajaran yang dihasilkan. Proses validasi ini melibatkan 3 (tiga) validator terdiri dari 2 (dua) dosen Prodi Pendidikan Matematika Universitas Negeri Yogyakarta dan seorang praktisi, yaitu guru konsultan MGMP Matematika SMP Kabupaten Magelang. Setelah produk yang dihasilkan dinilai valid dan layak digunakan, selanjutnya dilakukan uji coba.

Uji coba dilakukan dua tahap, yaitu uji coba skala kecil (small group try out) dan uji coba skala besar/uji coba lapangan (field try $o u t)$. Uji coba skala kecil dilakukan untuk menguji kualitas produk pengembangan pada skala kecil, meliputi keterbacaan, kemudahan/kesulitan, dan waktu yang dibutuhkan dalam pelaksanaan pembelajaran. Tahap uji coba ini melibatkan 12 siswa dengan kemampuan akademik tinggi, sedang, dan rendah, masing-masing 2 siswa yang dipilih dari 2 kelas berbeda. Keduabelas siswa tersebut diminta mengerja-kan LKS yang dihasilkan kemudian memberikan penilaian pada lembar penilaian siswa yang berkaitan dengan pertanyaan tentang lembar kegiatan siswa (LKS), yaitu pada bagian III-VI. Hasil uji coba ini digunakan sebagai dasar untuk melakukan revisi terhadap produk yang dikembangkan.

Adapun uji coba skala besar/uji coba lapangan (field try out) bertujuan untuk mengetahui kepraktisan (practicality) dan keefek-tifan (effectiveness) dari produk yang dikembangkan pada skala yang lebih besar. Tahapan ini dilakukan pada 2 (dua) kelas berbeda dari 6 (enam) kelas yang ada di SMPN 1 Muntilan yang diajar oleh 2 (dua) orang guru yang berbeda. Pada tahap ini dilakukan pembelajaran dengan dengan menggunakan perangkat pembelajaran geometri SMP yang dikembangkan. Di akhir kegiatan pembelajaran siswa diberikan tes yang hasilnya akan digunakan untuk menentukan keefektifan perangkat pembelajaran yang dikembangkan. Tahap ini dilaksanakan dalam proses pembelajaran selama 8 (delapan) pertemuan dalam waktu 3 (tiga) minggu. Hasil uji coba ini diguna- 
kan sebagai dasar untuk melakukan revisi terhadap produk yang dikembangkan.

Berdasarkan hasil uji coba lapangan (field try out), selanjutnya dilakukan revisi-revisi terhadap perangkat pembelajaran geometri SMP yang dihasilkan. Revisi dilakukan sebanyak 3 (tiga) kali berdasarkan hasil dari masing-masing uji coba. Revisi I dilakukan berdasarkan hasil uji coba ahli/validasi ahli (expert judgement). Revisi II dilakukan berdasarkan hasil uji coba kelompok kecil (small group try out). Adapun revisi III dilakukan berdasarkan hasil uji coba lapangan, meliputi penilaian guru dan siswa dari kelas-kelas uji coba, serta keterlaksanaan pembelajaran di kelas-kelas uji coba. Hasil revisi III selanjutnya digunakan sebagai dasar menyusun produk akhir pengembangan.

Jenis data dalam penelitian ini terdiri dari data kuantitatif dan data kualitatif. Data kuantitatif diperoleh dari skor yang diberikan oleh validator, skor penilaian guru dan skor penilaian siswa terhadap perangkat pembelajaran geometri SMP kelas VIII semester II, skor keterlaksanaan pembelajaran serta skor tes hasil belajar siswa. Data kualitatif diperoleh dari hasil konversi atas data kuantitatif yang diberikan oleh validator, skor penilaian guru dan skor penilaian siswa terhadap perangkat pembelajaran geometri SMP kelas VIII semester II.

Instrumen pengumpulan data dalam penelitian ini terdiri dari (1) lembar validasi, (2) lembar penilaian guru, (3) lembar penilaian siswa, (4) lembar observasi dan (5) tes hasil belajar. Data yang diperoleh digunakan untuk mengetahui kevalidan (validity), kepraktisan (practicality) dan keefektifan (effectiveness) dari produk yang dikembangkan.

Analisis data dilakukan untuk memperoleh bukti berkaitan dengan kevalidan, kepraktisan dan keefektifan produk yang dikembangkan berupa perangkat pembelajaran geometri SMP kelas VIII semester II. Hasil anali-sis data yang diperoleh dari para ahli dan praktisi digunakan untuk menentukan kevalidan produk yang dihasilkan dari segi teoritis dan kekonsistenan diantara komponen-komponen produk yang dikembangkan. Sedangkan hasil analisis data dari uji coba lapangan digunakan sebagai dasar untuk menentukan kepraktisan dan keefektifan produk yang dikembangkan.

Untuk keperluan tersebut dilakukan langkah-langkah: (1) membuat tabel konversi berdasarkan pengubahan skor penilaian ahli, guru, praktisi, dan siswa menjadi nilai standar skala lima; dan (2) mengkonversi data skor penilaian ahli, guru, praktisi, dan siswa menjadi nilai standar skala lima. Untuk keperluan ini digunakan patokan yang diadaptasi dari Azwar (1996, p.163). Hal ini dilakukan dengan menentukan skor minimum ideal, skor maksimum ideal, mean ideal, dan simpangan baku ideal, kemudian menentukan kriteria interval untuk masingmasing kategori.

Analisis data kevalidan perangkat pembelajaran dilakukan dengan cara mengkonversi data kuantitatif berupa skor hasil penilaian ahli dan praktisi terhadap masing-masing komponen (silabus, RPP, LKS, dan THB) menjadi data kualitatif. Hal ini dilakukan dengan cara mengkomunikasikan total skor yang diperoleh berdasarkan penilaian dari validator dengan kriteria yang telah ditetapkan. Produk pengembangan berupa perangkat pembelajaran geometri SMP yang dihasilkan dikatakan valid apabila tingkat validitas untuk masing-masing komponen memenuhi kategori minimal valid.

Analisis data hasil uji coba skala kecil (small group try out) dilakukan dengan cara mengkonversi data kuantitatif berupa skor hasil penilaian siswa pada masing-masing komponen (angket LKS bagian III-VI) menjadi data kualitatif. Hal ini dilakukan dengan cara mengkomunikasikan total skor yang diperoleh berdasarkan penilaian siswa dengan kriteria yang telah ditetapkan. Produk pengembangan berupa lembar kegiatan siswa (LKS) untuk pembelajaran geometri SMP yang dihasilkan dikatakan praktis apabila penilaian siswa me-menuhi kategori minimal baik.

Analisis data kepraktisan didasarkan pada dua hal, yaitu (1) penilaian dari guru dan siswa tentang kelayakan penggunaan perangkat pembelajaran geometri SMP di kelas, dan (2) hasil observasi keterlaksanaan pembelajaran menggunakan perangkat pembelajaran geometri SMP. Kepraktisan perangkat pembelajaran dalam penelitian ini dilihat dari konsistensi penilaian dari kedua sumber tersebut.

Analisis data yang berkaitan dengan penilaian guru dan siswa dilakukan dengan cara mengkonversi data kuantitatif berupa skor hasil penilaian pada masing-masing komponen menjadi data kualitatif. Hal ini dilakukan dengan cara mengkomunikasikan total skor yang diperoleh berdasarkan penilaian guru dan siswa dengan kriteria yang telah ditetapkan. Produk pengembangan berupa perangkat pembelajaran geometri SMP yang dihasilkan dikatakan praktis apabila penilaian guru memenuhi kategori minimal baik, 
dan minimal $80 \%$ siswa memberikan penilaian dengan kategori minimal baik.

Analisis data hasil observasi keterlaksanaan pembelajaran dilakukan dengan menghitung presentase keterlaksanaan setiap komponen pembelajaran geometri SMP kelas VIII semester II menggunakan metode penemuan terbimbing pada setiap pertemuan. Hasil ini kemudian dikomunikasikan dengan criteria yang telah ditetapkan. Produk pengembangan berupa perangkat pembelajaran geometri SMP dikatakan praktis apabila keterlaksanaan pembelajaran minimal mencapai kategori baik.

Analisis data untuk menentukan keefektifan perangkat pembelajaran geometri SMP yang dihasilkan dilakukan dengan cara mengolah data hasil tes belajar yang diperoleh siswa, meliputi kuis dan ulangan harian sebagai posttest. Produk hasil pengembangan berupa perangkat pembelajaran geometri SMP dikatakan efektif digunakan dalam proses pembelajaran di kelas apabila: (1) paling sedikit $80 \%$ siswa mencapai Kriteria Ketuntasan Minimal (KKM) yang telah ditetapkan, yaitu 80; dan (2) terdapat peningkatan persentase ketuntasan belajar secara klasikal berdasarkan hasil pretest dan posttest.

\section{HASIL PENELITIAN DAN PEMBAHASAN}

Tahap analisis kebutuhan dan perumusan tujuan dilakukan dengan cara mengkaji Standar Isi pada pembelajaran matematika SMP, khususnya pada materi pokok geometri. Selain itu juga melalui pengumpulan kuesioner, dan observasi di lapangan untuk mengumpulkan informasiinformasi awal yang mendukung produk yang akan dikembangkan. Hasil yang diperoleh pada tahap ini mencakup 3 hal, yaitu: (1) pentingnya pembelajaran matematika; (2) realitas pelaksanaan pembelajaran matematika; dan (3) metode yang sesuai untuk pembelajaran geometri.

Berdasarkan hasil analisis kebutuhan dan perumusan tujuan, tahap selanjutnya adalah tahap desain/pengembangan produk. Tahapan ini mencakup pengembangan materi, perumusan alat pengukur keberhasilan, dan pengembangan perangkat pembelajaran. Kegiatan dalam pengembangan materi mencakup analisis pembelajaran dan identifikasi karakter siswa. Perumusan alat pengukur keberhasilan dilakukan dengan menuliskan tujuan khusus (indikator pencapaian kompetensi) berdasarkan hasil analisis pembelajaran dan identifikasi karakter siswa. Analisis pembelajaran dilakukan dengan mengidentifikasi kurikulum pembelajaran matematika SMP yang mengacu pada Peraturan Menteri
Pendidikan Nasional (Permendiknas) No. 22 Tahun 2006 tentang Standar Isi mata pelajaran matematika. Adapun identifikasi karakter siswa dilakukan dengan cara mempelajari karakteristik siswa dari sekolah yang menjadi tempat uji coba, yaitu SMP Negeri 1 Muntilan. Proses ini didasarkan pada informasi tentang hasil belajar dari guru matematika di sekolah tersebut. Hasil tahapan ini berupa draft produk awal yang yang selanjutnya akan digunakan pada tahap uji coba untuk menentukan kualitas produk yang telah dihasilkan.

Berdasarkan draft produk awal yang diperoleh berupa perangkat pembelajaran geometri SMP yang terdiri dari silabus, RPP, LKS, dan THB, tahap selanjutnya adalah melakukan uji coba terhadap produk tersebut. Tahapan uji coba ini meliputi uji coba/validasi ahli (expert judgement), uji coba skala kecil (small group try out) dan uji coba skala besar/lapangan (field try out).

Proses validasi ahli melibatkan 3 (tiga) validator terdiri dari 2 (dua) orang dosen Prodi Pendidikan Matematika Universitas Negeri Yogyakarta dan seorang praktisi. Adapun dari unsur praktisi adalah konsultan MGMP Matematika SMP Kabupaten Magelang. Data skor validasi produk awal dari ketiga validator untuk masing-masing komponen perangkat berturutturut adalah: Silabus (368), RPP (492), LKS (260), dan THB (284). Berdasarkan kriteria kevalidan komponen perangkat pembelajaran yang telah ditetapkan dapat diketahui tingkat kevalidan masing-masing komponen perangkat pembelajaran tersebut berada pada kategori sangat valid. Data hasil analisis kevalidan perangkat pembelajaran dapat dilihat pada tabel berikut.

Tabel 1. Hasil Analisis Kevalidan Perangkat Pembelajaran

\begin{tabular}{cccc}
\hline No & Komponen & Total Skor & Kategori \\
\hline 1 & Silabus & 368 & Sangat Valid \\
2 & RPP & 492 & Sangat Valid \\
3 & LKS & 260 & Sangat Valid \\
4 & THB & 284 & Sangat Valid \\
\hline
\end{tabular}

Tahap uji coba skala kecil melibatkan 12 siswa dengan kemampuan akademik tinggi, sedang, dan rendah, masing-masing 2 siswa yang dipilih dari 2 kelas berbeda. Keduabelas siswa tersebut diminta memberikan penilaian pada lembar penilaian siswa yang berkaitan dengan pertanyaan tentang lembar kegiatan siswa (LKS), yaitu pada bagian III-VI. Proses ini dilaksanakan pada tanggal 7 Mei 2013. Dari data yang diperoleh, diketahui bahwa penilaian 
siswa dalam skala kecil untuk masing-masing LKS yang dihasilkan minimal berada pada kategori baik. Ini berarti LKS yang dihasilkan dikategorikan praktis dalam skala kecil. Hasil analisis kepraktisan berdasarkan penilaian siswa dalam sekala kecil disajikan pada tabel berikut.

Tabel 2. Hasil Analisis Kepraktisan Berdasarkan Penilaian Siswa pada Skala Kecil

\begin{tabular}{cccc}
\hline No. LKS & Skor & Nilai & Kategori \\
\hline 1.1 & 105 & B & Baik \\
1.2 & 108 & B & Baik \\
2.1 & 111 & A & Sangat Baik \\
2.2 & 115 & A & Sangat Baik \\
3.1 & 108 & B & Baik \\
3.2 & 113 & A & Sangat Baik \\
3.3 & 113 & A & Sangat Baik \\
\hline
\end{tabular}

Tahap uji coba lapangan dilakukan untuk memperoleh data hasil observasi keterlaksanaan pembelajaran, data penilaian siswa, data penilaian guru dan data tes hasil belajar. Data-data tersebut selanjutnya digunakan untuk mengetahui kepraktisan (practicality) dan keefektifan (effectiveness) perangkat pembelajaran geometri SMP yang dikembangkan. Pengambilan data ini dilaksanakan dalam proses pembelajaran selama 8 (delapan) pertemuan dalam waktu 4 (empat) minggu, yaitu minggu II-IV Mei dan minggu I Juni 2013.

Kepraktisan perangkat didasarkan pada tingkat keterlaksanaan pembelajaran dan hasil penilaian guru dan siswa. Berdasarkan data hasil observasi keterlaksanaan pembelajaran selama 7 (tujuh) kali pertemuan, diketahui bahwa ratarata rata-rata presentase keterlaksanaan pembelajaran di kelas VIII-A sebesar $85 \%$, VIII-C sebesar $86 \%$, dengan total rata-rata sebesar $85,34 \%$. Ini berarti bahwa rata-rata presentase keterlaksanaan pembelajaran pada kedua kelas maupun secara keseluruhan terletak pada interval $75 \%-100 \%$ dengan nilai A. Dengan demikian dapat disimpulkan bahwa keterlaksanaan pembelajaran menggunakan perangkat pembelajaran geometri SMP yang dihasilkan di lapangan memenuhi kategori sangat baik. Ini berarti perangkat pembelajaran geometri SMP yang dihasilkan memenuhi kategori sangat praktis untuk digunakan.

Kepraktisan juga didasarkan dari hasil penilaian guru. Dari data skor penilaian kedua guru setelah melaksanakan proses pembelajaran dengan produk perangkat hasil pengembangan, diketahui bahwa total skor penilaian yang diperoleh adalah $438>368$. Berdasarkan kriteria kepraktisan menurut penilaian guru yang telah ditetapkan, produk hasil pengembangan memenuhi kategori sangat baik. Data kepraktisan perangkat berdasarkan penilaian guru disajikan pada tabel berikut.

Tabel 3. Kepraktisan Perangkat Berdasarkan Penilaian Guru

\begin{tabular}{clcl}
\hline No. & Komponen & Skor & Kategori \\
\hline 1 & Silabus & 85 & Sangat Baik \\
2 & RPP & 112 & Sangat Baik \\
3 & LKS & 132 & Sangat Baik \\
4 & THB & 107 & Sangat Baik \\
& Total Skor & 438 & Sangat Baik \\
\hline
\end{tabular}

Di samping penilaian guru, kepraktisan juga didasarkan pada penilaian siswa. Berdasarkan data skor penilaian siswa pada setiap akhir pertemuan diketahui bahwa rata-ratanya adalah 58,52 (sangat baik), dengan persentase banyak siswa yang menilai minimal baik sebesar $84,78 \%$. Dari data skor penilaian siswa setelah keseluruhan proses pembelajaran berakhir diketahui rata-ratanya 57,65 (sangat baik), dengan persentase banyak siswa yang menilai minimal baik sebesar $85,42 \%$. Berdasarkan hasil analisis data tersebut diketahui bahwa rata-rata skor penilaian siswa selama proses dan di akhir pembelajaran memenuhi kategori minimal baik dengan persentase banyak siswa yang menilai baik melebihi $80 \%$. Hal ini menunjukkan bahwa perangkat pembelajaran geometri SMP yang dihasilkan memenuhi kriteria praktis.

Berdasarkan hasil analisis data observasi keterlaksanaan pembelajaran, penilaian guru dan penilaian siswa, dapat disimpulkan terdapat konsistensi penilaian yang baik/positif dari guru dan siswa serta tingkat keterlaksanaan pembelajaran yang sangat tinggi di lapangan. Hal ini menunjukkan bahwa perangkat pembelajaran geometri SMP yang dihasilkan memenuhi kriteria praktis untuk digunakan.

Analisis data keefektifan didasarkan pada data tes hasil belajar siswa meliputi pretest, kuis, dan posttest. Ringkasan hasil analisis berdasarkan data nilai hasil belajar tersebut disajikan pada tabel berikut.

Tabel 4. Hasil Analisis Hasil Belajar

\begin{tabular}{lcc}
\hline \multicolumn{1}{c}{ Jenis } & Banyak Siswa & Ketuntasan \\
\hline Pretest & 46 & $36,96 \%$ \\
Kuis & 46 & $84,78 \%$ \\
Posttest & 48 & $83,33 \%$ \\
\hline
\end{tabular}

Dari hasil analisis tersebut diketahui bahwa ketuntasan belajar setelah proses pembelajaran menggunakan perangkat yang dihasilkan 
secara keseluruhan telah memenuhi Kriteria Ketuntasan Minimal (KKM) yang ditetapkan. Berdasarkan hasil pretest dan posttest juga menunjukkan adanya peningkatan persentase ketuntasan klasikal sebesar 125,46\%. Dengan demikian perangkat pembelajaran geometri SMP yang dihasilkan telah memenuhi kriteria efektif.

Berdasarkan hasil uji coba pada tahap sebelumnya, selanjutnya dilakukan revisi-revisi terhadap perangkat pembelajaran geometri SMP yang dihasilkan. Revisi dilakukan sebanyak 3 (tiga) kali berdasarkan hasil dari masing-masing uji coba. Revisi I dilakukan berdasarkan hasil uji coba ahli/validasi ahli (expert judgement). Revisi II dilakukan berdasarkan hasil uji coba kelompok kecil (small group tryout). Yang terakhir, revisi III dilakukan berdasarkan hasil uji coba lapangan, meliputi penilaian guru dan siswa dari kelas-kelas uji coba, serta keterlaksanaan pembelajaran di kelas-kelas uji coba. Hasil revisi III selanjutnya digunakan sebagai dasar menyusun produk akhir pengembangan.

Revisi I dilakukan berdasarkan saran/ masukan validator dari hasil uji coba ahli. Revisi atau perbaikan dilakukan terhadap produk pengembangan berupa perangkat pembelajaran geometri SMP yang telah dihasilkan, meliputi silabus, rencana pelaksanaan pembelajaran (RPP), lembar kegiatan siswa (LKS), dan tes hasil belajar (THB). Secara ringkas saran/masukan validator yang dijadikan sebagai dasar revisi I disajikan dalam tabel berikut.

Tabel 5. Saran/Masukan Hasil Uji Coba Ahli

\begin{tabular}{cl}
\hline Komponen & \multicolumn{1}{c}{ Saran/Masukan } \\
\hline Silabus & $\begin{array}{l}\text { Perlu perbaikan kata kerja pada indi- } \\
\text { kator yang tidak terukur, langkah- } \\
\text { langkah kegiatan pembelajaran, dan } \\
\text { pembagian alokasi waktu masing- } \\
\text { masing KD. } \\
\text { RPP } \\
\text { Perlu perbaikan pada indikator dan } \\
\text { tujuan pembelajaran, kegiatan pem- } \\
\text { belajaran, materi ajar, penilaian, dan } \\
\text { beberapa soal kuis. } \\
\text { Perlu perbaikan pada struktur LKS, } \\
\text { beberapa gambar, tempat menuliskan } \\
\text { hasil penemuan, petunjuk pengirisan } \\
\text { rusuk untuk menemukan jaring-ja- } \\
\text { ring, penemuan rumus volume prisma } \\
\text { serta limas. } \\
\text { Perlu perbaikan pada redaksional } \\
\text { beberapa soal dan beberapa gambar. }\end{array}$ \\
\hline
\end{tabular}

Revisi II dilakukan berdasarkan hasil uji coba skala kecil. Kegiatan ini dilakukan dengan cara meminta beberapa siswa berdasarkan kategori prestasi akademik tinggi, sedang, dan rendah untuk menilai dan memberikan masukan atas produk pengembangan yang berupa lembar kegiatan siswa (LKS). Berdasarkan hasil dari kegiatan ini dilakukan revisi atau perbaikan produk pengembangan berupa LKS sebagai komponen pendukung perangkat pembelajaran geometri SMP yang telah dihasilkan. Beberapa revisi yang dilakukan pada tahap ini adalah mengubah beberapa kata/istilah, petunjuk dan bahasa, serta keterangan simbol dalam LKS.

Revisi III dilakukan berdasarkan saran/ masukan guru dan hasil pengamatan di lapangan dalam uji coba lapangan. Secara ringkas beberapa revisi tersebut disajikan pada tabel di bawah.

Tabel 6. Revisi Hasil Uji Coba Lapangan

\begin{tabular}{|c|c|}
\hline Komponen & Bagian yang Direvisi \\
\hline Silabus & $\begin{array}{l}\text { Menambahkan keterangan mengenai } \\
\text { sumber belajar yang digunakan. }\end{array}$ \\
\hline RPP & $\begin{array}{l}\text { Mengubah kegiatan siswa dan guru } \\
\text { pada kegiatan berdoa dengan menam- } \\
\text { bahkan keterangan apabila pembelajar- } \\
\text { an pada jam ke-1 (kegiatan 1.a) dan } \\
\text { apabila pembelajaran pada jam } \\
\text { terakhir (kegiatan 3.e) }\end{array}$ \\
\hline LKS & $\begin{array}{l}\text { Menambahkan beberapa kalimat } \\
\text { pembantu untuk membimbing siswa } \\
\text { dalam menemukan rumus volume } \\
\text { prisma dan limas. }\end{array}$ \\
\hline
\end{tabular}

Tahap terakhir yaitu kajian produk akhir adalah tahap penyusunan perangkat pembelajaran geometri SMP untuk kelas VIII berdasarkan revisi terkahir. Hasil dari tahapan ini selanjutnya menjadi produk akhir, yaitu perangkat pembelajaran geometri SMP untuk kelas VIII semester II yang valid dan layak untuk digunakan.

Catatan penting dalam pelaksanaan pembelajaran geometri SMP adalah masih terdapat beberapa tahap dalam kegiatan pembelajaran yang persentase keterlaksanaanya di bawah $80 \%$. Beberapa tahap tersebut adalah guru dan siswa mengawali kegiatan pembelajaran dengan berdo'a $(35,71 \%)$, siswa melakukan diskusi kelas atau tanya jawab $(57,14 \%)$, guru memberikan tugas mandiri/PR (50\%), serta guru dan siswa mengakhiri kegiatan pembelajaran dengan berdo'a (7,14\%). Hal tersebut dikarenakan guru dan siswa belum terbiasa melaksanakan proses pembelajaran dengan sistematis menggunakan metode tertentu yang memberikan kesempatan 
luas kepada siswa untuk membangun pengetahuannya.

Rendahnya keterlaksanaan tahapan berdo'a di awal dan akhir pembelajaran dikarenakan kebiasaan melakukan itu hanya pada jam pelajaran tertentu, yaitu di awal dan akhir pembelajaran. Persentase keterlaksanaan tahapan diskusi dan tanya jawab setelah presentasi hasil yang rendah juga dikarenakan siswa belum terbiasa melakukannya dalam proses pembelajaran. Sedangkan tahapan guru memberikan tugas mandiri/PR yang keterlaksanaannya masih rendah disebabkan oleh pemanfaatan waktu pada beberapa pertemuan yang belum efektif.

Berdasarkan kajian tersebut dapat disimpulkan bahwa hasil pengembangan perangkat pembelajaran geometri SMP menggunakan metode penemuan terbimbing untuk kelas VIII telah teruji kevalidan, kepraktisan, dan keefektifannya. Hasil analisis menunjukkan bahwa kualitas produk adalah baik, karena terbukti valid, praktis, dan efektif. Dengan demikian produk dapat digunakan dalam pembelajaran dan dapat digunakan sebagai contoh pada pengembangan pembelajaran matematika yang menggunakan metode dan materi pembelajaran yang lain.

\section{SIMPULAN DAN SARAN}

Pengembangan perangkat pembelajaran geometri SMP menggunakan metode penemuan terbimbing untuk kelas VIII semester II dilaksanakan sesuai dengan langkah-langkah pengembangan perangkat pembelajaran, yaitu: (1) analisis kebutuhan, (2) desain/pengembangan produk, (3) uji coba, (4) revisi dan (5) kajian produk akhir. Aspek-aspek yang dikembangkan dalam pengembangan perangkat pembelajaran geometri SMP menggunakan metode penemuan terbimbing adalah: (1) orientasi pada permasalahan; (2) menyiapkan alat dan bahan; (3) diskusi pengarahan; (4) kegiatan penemuan; (5) pembimbingan; (6) presentasi hasil; dan (7) pengembangan dan tindak lanjut. Hasil pengembangan adalah produk berupa perangkat pembelajaran geometri SMP untuk kelas VIII semester II, meliputi silabus, rencana pelaksanaan pembelajaran (RPP), lembar kegiatan siswa (LKS), dan tes hasil belajar (THB) yang baik dan layak untuk digunakan. Perangkat pembelajaran geometri SMP untuk kelas VIII semester II yang dihasilkan, yaitu silabus, RPP, dan LKS, masing-masing memenuhi kategori sangat valid, sangat praktis, dan efektif, sementara itu THB memenuhi syarat efektif dan sifat praktis.
Berdasarkan kesimpulan yang dikemukakan, maka beberapa saran yang perlu dipertimbangkan untuk peningkatan kualitas pembelajaran matematika sekolah, yaitu: (1) bagi sekolah, produk pengembangan dalam penelitian ini dapat manfaatkan sebagai salah satu contoh perangkat pembelajaran yang dapat digunakan untuk pengembangan perangkat pembelajaran pada mata pelajaran matematika; (2) bagi guru, produk pengembangan dalam penelitian ini dapat dimanfaatkan sebagai contoh alternatif dan contoh pengembangan perangkat pembelajaran matematika menggunakan metode penemuan terbimbing pada materi pokok geometri atau materi pokok lain yang sesuai; dan (3) bagi MGMP Matematika, produk pengembangan dalam penelitian ini dapat dimanfaatkan sebagai salah satu contoh perangkat pembelajaran yang dapat diadopsi dalam kegiatan pengembangan perangkat pembelajaran.

Perangkat pembelajaran geometri SMP yang dihasilkan, meliputi silabus, rencana pelaksanaan pembelajaran (RPP), lembar kegiatan siswa (LKS), dan tes hasil belajar (THB) pada materi bangun ruang sisi datar telah teruji kelayakannya, yaitu telah memenuhi kriteria valid, praktis dan efektif, sehingga layak digunakan dan dapat dimanfaatkan untuk kegiatan pembelajaran di kelas-kelas pada jenjang yang sama. Metode penemuan terbimbing yang digunakan pada pengembangan perangkat pembelajaran dalam penelitian ini terbukti sangat efektif digunakan pada materi geometri yang memiliki objek cukup abstrak. Hal ini dapat digunakan sebagai salah satu referensi bagi para guru/peneliti lain untuk menggunakan metode tersebut dalam kegiatan pengembangan lebih lanjut pada perencanaan proses pembelajarannya pada materi yang lain.

\section{DAFTAR PUSTAKA}

Alfieri, L., et.al, (2011). Does discovery-based instruction enhance learning? Journal of Educational Psychology, Vol. 103, No. 1, 1-18.

Altman, H.B., \& Cashin, W.E. (1992). Writing a syllabus. Idea Paper, No. 27, Kansas State University.

Azwar, S. (1996). Tes prestasi-fungsi dan pengembangan pengukuran prestasi belajar (Edisi II). Yogyakarta: Pustaka Pelajar Offset. 
BSNP. (2006). Peraturan Menteri Pendidikan Nasional RI Nomor 22, Tahun 2006, tentang Standar Isi untuk satuan pendidikan dasar dan menengah.

BSNP. (2007). Peraturan Menteri Pendidikan Nasional RI Nomor 41, Tahun 2007, tentang standar proses untuk satuan pendidikan dasar dan menengah.

Depdiknas (2002). Pendekatan kontekstual (Contextual teaching and learning $(C T L)$ ). Dirjendikdasmen-Direktorat PLP: Jakarta.

Depdiknas. (2005). Peraturan Pemerintah RI Nomor 19, Tahun 2005, tentang standar nasional pendidikan.

Depdiknas. (2008). Pengembangan Rencana Pelaksanaan Pembelajaran (RPP). Jakarta: Dirjendikdasmen.

Disdikpora. (2011). Dokumen laporan penggunaan blockgrant pemberdayaan tahun 2011. Kabupaten Magelang: MGMP Matematika.

Dick, W., Carey, L. (1978). The systematics design of instruction $\left(6^{\text {th }} e d\right.$.). Oakland, NJ.,: Scot, Foresman and Company.

Ediger, M., \& Rao, D. B. (2010). Effective school curriculum. New Delhi: Arora Offset Press.

Krismanto, Al. (2003). Beberapa teknik, model, dan strategi dalam pembelajaran matematika. Tersedia: http://www.p4tkmatematika.org (Diakses tanggal 17 Maret 2011)

Lestari, S. (2008). Metode pembelajaran discovery dengan pendekatan konstruktivis untuk meningkatkan hasil belajar matematika pokok bahasan bangun datar pada siswa kelas VII SMP Negeri 11 Samarinda. Jurnal Didaktika, Volume 9 Nomor 3.

Moon, B., Mayes, A. S., \& Hutchinson, S. (Ed.). (2002). Teaching, learning and the curriculum in secondary school. New York: RoutledeFalmer.

Moursund, D. (2012: 11). Good math lesson planning and implementation. Tersedia: http://i-a-e.org/downloads/ doc_download/230-good-mathlessonplans.html (diunduh tanggal 8 Agustus 2012).

National Council of Teacher of Mathematics. (2000). Principles and standards for school mathematics. Reston: NCTM.

Nitko, A.J., \& Brookhart, S.M. (2011). Educational assessment of students. USA: Pearson.

O’Brien, J., D., Millis, B. J., \& Cohan, M., W. (2008). The course syllabus $\left(2^{\text {nd }} e d.\right)$. San Fransisco: John Wiley \& Sons, Inc.

Singer, A., J. (2003). Teaching to Learn, Learning to Teach-A Handbook for Secondary School Teachers. New Jersey: LEA.

Suck, S., \& Pereira, P. (Ed.). (2011). What counts in teaching mathematics. London: Springer.

Westwood, P. (2008). What teachers need to know about teaching methods. Camberwell Victoria: ACER Press.

Van de Wale, J. A., Karp, K. S., \& BayWilliams, J. M. (2010). Elementary and Middle School Mathematics-Teaching Developmentally $\left(7^{\text {th }}\right.$ ed.). Boston: Pearson Education, Inc. 